\title{
Digital danning med m-læring?
}

Danningsdidaktiske perspektiv på laring med digitale ressursar

\author{
Av Kåre Fuglseth
}

Sammendrag: Artikkelen presenterer og dreftar m-loering $i$ lys av danningsdidaktiske teoriar for å utvikle kunnskap om loerarens profesjonsfaglege digitale kompetanse. M-loering er loering med mobile einingar som mobiltelefon og nettbrett. Artikkelen byggjer på resultat frå eit prosjekt gjennomfort blant RLE-lararstudentar om digitale laringsressursar i filosofi- og etikkundervisning. I utgangspunktet starta prosjektet med ei skeptisk haldning, men vi vart positivt overraska. Terskelen for bruken er sars låg, og dei teknologiske loysingane er stabile, enkle og intuitive. Sarleg dei kreative og aktiviserande verktøy som ligg i desse, gjev nyttig danningspotensiale. Artikkelen viser òg til ei rad klassiske danningsdidaktiske problemstillingar som i mote med digital teknologi fär ny aktualitet, og som er til god hjelp for loeraren. Det er lett å gloyme at innhaldselementet $i$ undervisninga legg premiss for undervisningsmetoden. Danningsteorien om undervisning som "peiking» frå den tyske pedagogen Klaus Prange blir ei sarleg god hjelp til å forstå det som skjer i m-laring.

Nøkkelord: IKT, danning, m-læring, religion og livssyn, etikk, filosofisk samtale, dybdelæring

KARE FUGLSETH (f. 1959), professor i fagdidaktikk, Nord universitet, Pb. 1490, 8049 Bodø. E-post: kare.s.fuglseth@nord.no

EI SKEPTISK HALDNING TIL DIGITALE L ÆRINGSRESSURSAR? Denne artikkelen er ei drøfting av digitale læringsressursar i lys av danningsdidaktiske teoriar. Den teoretiske avklaringa i artikkelen er vokse fram av eit systematisk arbeid med bruk av slike læringsressursar i lærarutdanninga. Eg byggjer på resultat frå ei gjennomført undersøking om bruk av IKT i undervisning blant studentar i grunnskulelærarutdanning (sjå nedanfor og Fuglseth, red. 2018 «Kategorial danning og bruk av IKT i undervisning»). I denne samanhengen fører eg sider ved undersøkinga vidare ved å sjå prinsipielt på bruk av digitale læringsressursar generelt og m-læring spesielt. $M$-læring er organisert læring ved hjelp av mobile einingar som mobiltelefon og nettbrett. Tilsvarande viser $\mathrm{m}$-undervisning til lærarens arbeid med m-læring, noko som heng saman med lærarens profesjonsfaglege digitale kompetanse.

M-teknologien spreier seg raskt med den lette tilgangen, og studiet av det som skjer med bruken i skulen, har vanskar med å henge med utviklinga. Vi er midt i ei større omlegging av læringsressursar og læringsmiddel. Den digitale dugleiken

Prismet - IKO-Forlaget 2020

Tilgjengelig på https://journals.uio.no/index.php/prismet. Publisert under CC BY-NC 4.0. Fagfellevurdert

Årgang 71, hefte 1, s, 45-58

ISSN: 0032-8847, ISSN online:2535-311x 
blir i læreplanane sett på som grunnleggjande for elevane, på line med å skrive, tale (munnleg dugleik) og rekne. Det er, og har vore, store politiske og pedagogiske ambisjonar for den digitale teknologien. Men det har òg vore ein viss skepsis. I tillegg til alle dei tekniske utfordringane som bruken framleis fører med seg, kan ein spørje om nytten. Mykje programvare er først og fremst utvikla med tanke på underhaldning. Framvoksteren av teknologien er dominert av dette og eignar seg kanskje best til det òg. Det er ikkje uvanleg i Noreg å ta ein posisjon i dette ordskiftet mellom optimistane og pessimistane, ein mellomposisjon der ein er skeptisk til den store læringseffekten i høve til ikkje-digital teknologi, men likevel ikkje er negativ til å prøve (sjå Haugsbakk 2010, s. 12 ff.).

Vi byrja i vårt prosjekt òg med ei slik skeptisk, men likevel nysgjerrig haldning til bruken av digitale læringsressursar. I samband med undervisning av religionsog livssynsfag og andre kulturfag, er det lett å tenkje seg at bruken av spel i skulen lett kan ta merksemda bort frå dei definerte læringsmåla og føremåla med skulen (Buck 2017). Men bruksmåtane med den digitale teknologien er mange, og konklusjonar bør byggje på studiar av den faktiske bruken. Å finne ut av kva for verknader slike verktøy har på undervisninga, skjer heller ikkje i eit teoretisk tomrom.

Det som særleg opptok oss i prosjektet vårt, var korleis ein kan bruke kreative verktøy som kjem med den mobile teknologien. Vi oppfatta i utgangspunktet desse som dei mest lovande nye sidene ved den mobile teknologien i lys av danningspedagogiske vurderingar som legg vekt på metodar som kan skape sjølvstende og autonomi. Med kreative verktøy kan ein til dømes aktivisere barn og unge i fagemne ved å gjere video- og lydopptak og redigere desse til filmar og radioprogram. I verktøya har ein tilgang til ferdige malar som gjev tilgang til sjangermodular for filmar til dømes. I didaktiske analysar av denne bruken må vi òg sjå undervisningsteknologi, metodar og innhaldet i lag. Då står vi overfor utfordringar av to slag, for det første dei teknologiske (sjå del 2), dei som spør kva for bruksmåtar teknologien legg opp til, og for det andre dei pedagogiske (del 3), som seier noko om føremålet med undervisninga i eit meir heilskapleg fagsyn. Etter å ha gjort greie for det teknologiske og danningspedagogiske grunnlaget for analysen skal eg (del 4) trekkje fram analysen med materiale frå det opphavlege prosjektet. I dei siste delane (5-7) skal eg presentere og drøfte om skepsisen til teknologien er grunngjeve i fag som handlar om religion og livssyn, eller om det meir byggjer på ugrunna fordommar.

\section{TEKNOLOGIENS «LOGIKK»}

I samband med innføringa av digitale læremiddel eller ressursar vert det snøgt eit spørsmål om det vi kan kalle teknologiens logikk, dvs. det teknologien naturleg legg til rette for av aktivitetar. Dette er den teknologiske delen av ein slik studie. 
For å forstå det, må vi kjenne til mediets innebygde og naturlege føringar i pedagogisk bruk. Digitale leksikon er i utgangspunktet ikkje prinsipielt forskjellige frå papirleksikon når det gjeld innhaldet; det står det same, men er lettare tilgjengeleg på ein annan måte. Sit vi igjen med så mykje anna? Instruksjonsfilmar i digitale format er heller ikkje akkurat så ulik filmar i andre format. Dei er fleire bruksmåtar, ja- men fungerer dei nye eigentleg så annleis når det kjem til læring? Nøkternt sett er det kanskje ikkje så mykje nytt vi kan gjere med digital teknologi som ein ikkje før kunne gjere utan. Digitaliseringa har for det meste vore ein remedialisering av tidlegare tekniske funksjonar med ikkje-digitale løysingar (jf. Nordkvelle 2007). Men likevel er det skilnader, og den fremste skilnaden er at vi no alle kan bruke funksjonane på ein enkel måte. Dette handlar om tilgang. Når den digitale teknologien overtar dei analoge løysingane, senkar han terskelen for bruken. I tillegg har teknologien nokre fleire funksjonar enkelt tilgjengeleg. Dei tidlegare analoge systema var relativt dyre og tungvinte og kunne krevje spesialkompetanse i bruk og vedlikehald på ein heilt annan måte enn det digitale.

Undervisningsteknologi legg føringar på fagstoffet, på utvalet og vår evne til å handle med og gjennom teknologien. Dette tilleggsaspektet ved teknologi generelt vert kalla «affordansen», kva ein type teknologi skapar av moglege handlingar (jf. Gibson 1977). Puentedura (2009) peikte på at ny teknologibruk i undervisning anten kan erstatte, auke, styrke eller omdefinere oppgåvene elevane skal arbeide med («substitution, augmentation, modification and redefinition» = SAMR-modellen). I dette skiljet ligg det ikkje ei vurdering av om det eine er betre enn det andre. Men meirverdi-tanken føreset at det skjer noko meir enn eit erstatningsskifte («substitution»).

Spørsmålet i dag er om denne endringa òg kan seiast å føre til forbetring. Ei sentral problemstilling i møte med ny teknologi i pedagogiske samanhengar har difor vore kva vi kan gjere med han som vi før ikkje kunne gjere i læringsarbeidet utan denne, om han i tillegg fører til betre kunnskapstileigning og forståing enn det vi tidlegare kunne gjere i det aktuelle faget eller emnet. Dette er spørsmålet om pedagogisk meirverdi (jf. Fossland, 2015, s. 123 et al.; Fuglseth 2007).

Men vi kan likevel spørje om ikkje kravet om meirverdi har mist meining. Utbreiinga av alle mobile einingar endrar på ein måte vilkåra for all undervisning, med planlegging, gjennomføring og vurdering. Den teknologiske utviklinga går no så snøgt at sjølve spelereglane endrar seg (jf. drøftingane i Castells 1996, 2001; Lund 2003; Krumsvik 2016, s. 12). Vi kan i dag ikkje minst kombinere opne, kreative verktøy med kommunikasjonsprogram, nettressursar, bøker og andre informasjonskjelder, og med spesialprogramvare og digitale læringsmiddel. I mange kommunar, som i Bodø, får alle elevar frå første klasse no utdelt iPad, der alle slike funksjonar er integrerte. Desse brukar lærarane som kommunikasjonsverktøy med heimen, som presentasjonsverktøy, lærebok og læringsressurs. Med 
mobile einingar har vi òg verktøy som kan reagere dynamisk eller automatisk og interaktivt med e-meldingar eller GPS-signal, t.d. at nye oppgåver dukkar opp på visse punkt i terrenget eller i bygatene, på eit museum e.1. avhengig av ønska og responsen frå brukarane.

Når utviklinga har gått så raskt på denne måten, blir det til slutt meir eit spørsmål om å utnytte dei ressursane og midla til læring lærarane faktisk har tilgang til, og om å utnytte dei best mogleg i ei kritisk vurderande haldning. Korleis kan vi best planleggje undervisninga med desse ressursane og læringsmidla vi har til disposisjon? Når teknologien erobrar alle læringsressursar, må vi difor heller prøve å skjøne kva alle desse digitale funksjonane fører med seg når han vert teken i bruk på godt og vondt. Dette er eit stort felt som krev vurderingar gjennom teoretiske avklaringar og empiriske studiar. Ikkje nokon teknologi, heller ikkje mobile einingar som læringsressurs eller læremiddel, er nøytral. Til grunn for slike vurderingar av denne teknologen i undervisninga høyrer difor didaktiske og andre pedagogiske analysar.

\section{DIDAKTISK ANALYSAR AV DIGITALE LÆRINGSRESSURSAR}

Med læringsmiddel meiner ein opplegg som er laga med eit direkte læringsføremål, i motsetnad til læringsressursar som i utgangpunktet ikkje var laga for det. På ein måte er alle dei digitale læringsmidla vi her snakkar om, alltid òg middel til læring. I studiar av kva for middel dette er i denne samanhengen, kva den nye teknologien kan gjere og ikkje gjere, er det mogleg å velje fleire ulike perspektiv som på eitt vis overlappar kvarandre. I religionsdidaktiske vurderingar av ulike læringsmiddel er det avgjerande å sjå den samanhengen læringsresursar står i ved bruk, som ein del av spørsmålet om korleis vi skal arbeide som lærarar. «Design» er eit ord vi kan bruke om å planleggje undervisning i slike rike læringsmiljø ut frå sosiokulturelle teoriar om læring (Lund og Hauge 2011; Lund, Bakken og Engelien 2013). I studien av bruken av mobile einingar i lærarutdanninga studerte vi spørsmålet ut frå eit danningsdidaktisk perspektiv (jf. Fuglseth, red. 2018) ved å leggje opp til ei drøfting av innhaldsmomentet, kva studentane sat att med. Slike danningsteoriar har òg tidlegare har vore brukt til å seie kva «digital danning» kan vere i lys av skulens demokratiske oppdrag og føremål (jf. òg Beck 2009; Beck og Øgrim 2011; Beck et al. 2015).

Den danningstilnærminga eg nyttar meg av, er ikkje direkte med i planane for utviklinga av den digitale dugleiken i skulen, men er likevel indirekte med. Den digitale dugleiken er av Utdanningsdirektoratet $(2012$, s. 6) stilt opp med fire område: «[t]ilegne og behandle; produsere og bearbeide; kommunisere; digital dømmekraft». Allmenndanninga kan tenkjast inn i dette som eit aspekt, men som vi skal sjå, kjem det særleg fram i samband med å «bearbeide» informasjon. Sjølv om danningstilnærminga kan oppfattast som annleis enn den sosiokulturbaserte 
teorien i vygotskytradisjonen, kan ein òg sjå på dei to teoretiske tilnærmingane som to sider av same sak. Danningsteoriar kan òg vere tufta på sosiokulturelle teoriar, og til sjuande og sist rettar sosiokulturelle teoriar i utdanning seg mot utvikling av autonomi (jf. Fuglseth 2010).

Eit sentralt problem danningsteoriane prøver å løyse, er det pedagogiske danningsparadokset. Paradokset peikar på at om vi ønskjer oss sjølvstendige barn og unge, kan vi i prinsippet ikkje krevje at dei gjer som vi seier, for då endar vi i ein slags moralisme og med usjølvstendige vaksne. Det same vil gjelde for identitetar av alle slag. Kan vi og i kor sterk grad kan vi, fortelje barn og unge kva dei skal tru og gjere? Paradokset kjem særs godt fram i samband med undervisning om religion, livssyn og etikk i både skule og kyrkje og har vore eitt av dei største diskusjonstema i KRLE/RLE-fagets fagdidaktikk.

\section{DANNINGSDIDAKTIKK OG STUDIAR AV DIGITALE LERINGSRESSURSAR}

Det finst ingen enkle løysingar på dette paradokset. Men det finst mange gode forslag. For å konkretisere den didaktiske analysen av danningseffekten i digital teknologi, trekkjer eg vekslar på tre tyske teoriar om undervisning og danning som alle meiner å ha funne gode løysingar. Desse er Wolfgang Klafki, Dietrich Benner og Klaus Prange. Det meste av det desse tre nemnde forskarane har skrive, er på tysk og er ikkje sett om til andre språk, noko som gjer dei mindre tilgjengelege og såleis mindre brukt $i$ dagens didaktiske teoretiseringar utanfor tyskspråklege land. På bakgrunn av tilnærmingane deira argumenterer eg nedanfor for at didaktisk analyse krev fire grep:

1 for det første at ein må sjå samanhengen mellom form og stoff

2 for det andre at all undervisning både er partikulær og universell eller handlar om samanhengen mellom enkeltdøma og kategorien dette er døme på

3 for det tredje at vi må forstå undervisning som ei form for «peiking»

4 for det fjerde at undervisning må ha eit verdihierarki samstundes som ho er ikkje-stadfestande.

Dette er alle fire måtar vi brukar for å løyse danningsparadokset eller ein måte å forstå det på i didaktisk praksis. Eg skal sjå nærare på dei etter tur.

Utgangspunktet var korleis vi best kan utnytte digitalteknologien i fag der forståing og danning eller sjølvstende og autonomi er sentrale siktemål. Vi lyt då for det første (1) spørje kva teknologien opnar opp for generelt, både i høve til formale sider ved undervisning (som å lære å lære) og dei materiale (å lære noko). Ein slik studie føreset òg at vi ser på dei formene for kommunikasjon og dialog som utviklar seg i og med bruken, anten det dreier seg om undervisning $i$ skule eller kyrkje. Men å drøfte teknologi og andre læringsressursar utan å drøfte 
innhaldet kan samanliknast med å «strikke utan garn», som dei tyske didaktikarane Jank og Meyer (2011, s. 31) så treffande seier det. Studiar av læreprosessar med digital teknologi er i dag dessverre oftast berre formale, noko som fører til særs mangelfulle analysar. Formuleringane kring måla ved dei grunnleggjande dugleikane og kjerneområda i læreplanane, lid ofte under den lagnaden at dei berre er formale og såleis berre delvis til hjelp (jf. Fuglseth 2018a).

Men i didaktiske analysar er det for det andre (2) ikkje berre innhaldet interessant $i$ og for seg, men òg kriteria for utvalet. Vi kan spørje kva for kategoriar undervisningsdøma viser til, slik Klafki $(1963,1964,2002)$ gjorde det og slik dei to danske didaktikarane Hansen og Skovmand (2011) gjer det i klafkiansk ånd. Ei forteljing, til dømes, viser alltid òg til noko ut over seg sjølv, til ein overordna konkret (som «hest») eller abstrakt kategori (som «kjærleik»). Soga om den miskunnsame samaritanen frå Lukasevangeliet (Luk 10) er til dømes ei medviten fiktiv eksempelforteljing som peikar ut over seg sjølv, i dette tilfellet til abstrakte omgrep som nestekjærleik eller fiendekjærleik. Dette gjeld òg alle døme i undervisning, dei peikar ut over seg sjølv til ein overordna kategori. I planlegginga av undervisninga er det såleis viktig å velje ut gode døme som peikar eller kan peike på sentrale kategoriar slik at elevane kan kjenne att kategoriane når dei i framtida møter nye døme, døme som ingen i dag kanskje kjenner til.

Ein tredje måte å løyse danningsparadokset på for læraren er berre å vise fram for elevane kva vi alle står overfor. Dette har for det tredje (3) den tyske didaktikaren Klaus Prange utvikla til ein teori om undervisning som peiking. Ein slik teori kallast òg indeksikal. Tankegangen er at andre ikkje kan lære for oss, det må vi gjere sjølve, anten individuelt eller i lag med andre. Det einaste ein lærar då eigentleg kan gjere, er å peike på det som eleven eller studenten skal lære. Prange har sett på alle former for undervisning og har kategorisert dei utifrå deira ulike måtar å peike på. Han meiner at ein lærar i undervisninga er indeksikal på minst fire måtar. Ho kan:

1 vise fram noko (presentere, ostensivt)

2 framstille noko (representativt)

3 utfordre (direktivt)

4 gje tilbakemelding på (reaktivt). ${ }^{1}$

Å dra på ekskursjon til ei kyrkje, eit anna gudshus eller seremonirom vil vere ei presenterande peiking, medan å teikne eller på annan måte representere dette huset på skulen vil vere representativ. Det same vil gjelde for å vitje ei kyrkje eller liknande som er presentert på papir eller digitalt, det er snakk om representa-

1 Sjå Prange (2005) og Prange og Strobel-Eisele (2015). Terminologien på tysk er: a) «Ostensives Zeigen» - utpeikande og Øving, Übung. b) «Repräsentatives Zeigen» - framstelling, representativ, Darstellen. c) «Direktives Zeigen» - utfordrande, Auffordern. d) «Reaktives Zeigen» - tilbakemeldande, Rückmelden. Brinkmann (2012) har i sin store studie av «Øving» argumentert for at øving er ein eigen kategori, og at vi bør operere med fem peikingstypar. 
sjonar. I skulens KRLE-fag er det grunn til å tru at den utfordrande eller direkte formanande bruken er særs avgrensa (sjå Fuglseth 2013).

I lys av denne teorien kan ein lærar ikkje velje om ho vil peike, vi peikar alltid som lærarar på noko. Det er berre snakk om korleis og i kva grad vi gjer det. Denne peikinga skil læring i skule, kyrkje eller anna organisert samanheng frå læring meir allment. Vi kan vidare kombinere dei to innsiktene frå Klafki (samanhengen form og stoff og kategorial forståing) med innsiktene frå Prange (undervisning som peiking) og seie at ein lærar i all undervisning peikar både på det konkrete og det generelle, det er alltid snakk om ei slags dobbelpeiking. Ein lærar vil altså alltid «peike dobbelt».

Ei fjerde løysing (4) på danningsparadokset er det såkalla ikkje-stadfestande eller non-affirmative danningsidealet frå den tyske (religions)-pedagogen Dietrich Benner (jf. Benner 2015, s. 82). Vi kan ikkje ha ein skule utan eit visst verdisett, det er bakt inn så og seie i skulen som institusjon, altså at nokre verdiar er viktigare enn andre, meiner Benner. I Noreg har vi lagt desse inn i Opplæringslova. Verdiane i føremålsparagrafen i skulen er døme på det siste: «respekt for menneskeverdet og naturen, på åndsfridom, nestekjærleik, tilgjeving, likeverd og solidaritet». (Grunnskulelova 2016, par. 1-1). Til dømes kan vi seie at likeverd er betre enn diskriminering. Verdi er her teken i vid meining, noko som òg gjeld negative verdiar og ukultur. Dette kallar Benner ei hierarkisk løysing for verdiar i undervisning. Samstundes må ein ikkje setje opp faste mål for kvar elev eller student, t.d. ein fast identitet eller politisk eller religiøs overtyding. Slik Benner ser det, må undervisninga difor tenkjast a-teleologisk, dvs. utan eit konkret mål for den personlege utviklinga hjå barnet. Dette gjev oss òg ei konkret løysing på danningsparadokset i eit fleirreligiøst samfunn, og eit svar på spørsmålet om utvikling av identitet i skulen sitt KRLE-fag eller i trusopplæring i kyrkjelege samanhengar.

Vi kan overføre den non-affirmative eller ikkje-stadfestande løysinga (4) både til studiet av læringsmiddel og til empiriske klasseromstudiar, eller til andre undervisningsstudiar som ei form for tolkingsnøklar. Dette byggjer samstundes på dei tre andre løysingane ovanfor. Vi ser då ikkje berre på kva former undervisninga og læringsmidla peikar på, men òg på innhaldet (1). Vi ser vidare på kva for kategoriar som vert resultatet av undervisninga med desse læremidla (2). Samstundes studerer vi kva som vert peika på og som eleven igjen vil kunne peike på for sin eigen del (3). Dette er noko vi kan studere empirisk og teoretisk, og denne utforskinga kan vi kalle kategorial (jf. Fuglseth 2018, s. 127). I slik utforsking ser vi på konsekvensar av gjennomført undervisning så langt råd er (jf. Fuglseth 2013). Den kategoriale utforskinga kan vi gjere både teoretisk og empirisk. I studiet av bruken av m-undervisning og m-læring overfører vi dette grunnlaget til ein studie, om teknologien legg til rette for sjølvstendiggjering og er allmenndannande, ikkje berre i høve til bruken av dette mediet. 


\section{STUDIET AV M-UNDERVISNING OG M-LARING}

Med utgangspunkt $\mathrm{i}$ desse to teoretiske avklaringane ovanfor (teknologisk og pedagogisk), skal eg i denne delen trekkje fram nokre innsikter frå det nemnde iPad-prosjektet, «Fleksibel læring i RLE».

Prosjektet var eit samarbeidsprosjekt mellom lærarutdanningane i Nord-Noreg, dvs. Nesna, Bodø og Tromsø om undervisning av faget religion, livssyn og etikk (RLE) i lærarutdanninga i den fireårige grunnskulelærarutdanninga, gjeldande frå 2010 til 2017 då den nye femårige utdanninga tok over. Prosjektet fekk stø frå Norgesuniversitetet og lærarutdanningsinstitusjonane i regionen innanfor det nasjonale SAK-prosjektet i høgare utdanning. ${ }^{2}$ I SAK-prosjektet ønskte regjeringa å få utdanningsinstitusjonane til å samarbeide og koordinere. Våre eigne institusjonar var med på å finansiere prosjektet ved å kjøpe inn nettbrett (iPad mini) til alle studentane som valde RLE-emnet. Emnet var ikkje obligatorisk, men vifta av moglege fagemne for studentane var relativt smal. Studentane fekk låne nettbretta i ein periode frå tre til seks månader. Poenget med denne delen av prosjektet var at vi skulle eksperimentere mest mogleg med gratisprogramvare og dei programma som då var tilgjengelege via Uninetts teneste e-Campus, og vi ønskte å gjere det i lys av danningsdidaktiske forskingsspørsmål, den kategoriale utforskinga (jf. ovanfor). Med desse mobile einingane kunne vi sjå nærare på den faktiske bruken av digitale læringsressursar med lyd, film og bilete, i læringsarbeid med mobile einingar (m-læring) og dei konkreta resultata det førte til. Studiet var samlingsog nettbasert, noko som tyder at dei fysiske møta mellom lærarar og studiet vert redusert i høve til vanleg campus-undervisning. I eit slikt studium vert meir av læringsarbeidet tufta på digital teknologi, og det er difor òg sentralt å vurdere det i lys av dei danningsmåla som er nedfelt i RLE-studiet og danningsteoriar. Dei digitale ressursane i bruk legg føringar på undervisningsstoffet, det opnar for nye medium og kanskje såleis òg for nye danningsvegar.

I den aktuelle utprøvingsperioden samla vi vel 40 presentasjonar sentrert rundt tema frå bibelsoge og frå etisk refleksjon. Oppdraget til studentane var å lage små introduksjonar som kunne motivere for vidare refleksjon hjå framtidige elevar:

Studentane skal lage eit produkt til bruk i ein klasse eller gruppe elevar (1-7 eller 5-10) i RLE ved hjelp av

iPad e.l., og dette skal kunne presenterast på iPad-en og skal leverast inn på Fronter. Emnet for oppgåva kan ein hente frå heile RLE-faget i grunnskulen.

Studentane brukte i stor grad ferdige malar (for å lage «trailers») tilgjengelege med iPad, iPhone og liknande Apple-produkt. Når vi har slike malar, vil vi i endå større grad senke tersklane for bruk av slike sjangerbestemte opplegg

2 https://espresso.siu.no/projects/;jsessionid=ig2bd4ye8c2g1lk36r0jczzcl?0 


\section{DOBBEL PEIKING OG RESPONSIV TILBAKEMELDING}

Eg har tidlegare presentert ein analyse av videoar studentane laga om etiske problemstillingar (Fuglseth 2018a). Fire videoar var laga med redigeringsverktøy med ferdige malar for prøvesmaking (trailer) av filmar. Desse fire studentfilmane handla konkret om øyding av vatn, abort, øyding av mat og om ærlegdom meir generelt. Temavalet er etisk, dvs. dei kan utfordre oss alle på handlingsval. Dei etiske refleksjonane i filmane og i refleksjonen kring filmane studentane laga, vart påståelege, noko som eg oppfattar som eit resultat som filmmalen styrkjer. Den moralske bodskapen var ikkje berre hierarkisk i høve til ibuande og usagte verdiar, noko som ikkje er til å unngå, men direkte moraliserande (du skal ikkje stele, øyde ressursar o.1.). Spørsmålet er så om vi kan kalle dei stadfestande (affirmative), noko som ville i strid med målsettinga i den danningsteoriar presentert ovanfor om møtet mellom lærar og elev. Så enkelt er sjølvsagt ikkje dette.

Filmformatet legg vel til rette for slike sterke utfordringar, form og stoff heng lett i hop. Når filmane på denne måten vart påståelege, vert dei først og fremst prega av det Prange kallar direkte eller utfordrande peiking. Filmane gjev kraftige døme for store kategoriar. Slik sterk peiking kan nok fort gje undervisninga ein nærast forkynnande karakter. Men dette er likevel ikkje direkte kommunikasjon, det er indirekte, og bodskapen misser noko av sin overtalande og stadfestande eller affirmative karakter då. Med indirekte i denne samanhengen meiner eg at det ikkje er læraren eller studenten som seier dette til elevane, det er læraren som seier det på ein film til elevane. Bodskapen er mediert eller formidla, i klasserommet vil det fungere i ein ny kontekst med eit anna føremål enn å overtale. I bruken av slike filmar i klasserommet får filmmakaren, her lærarstudenten i klasserommet, ein type metaposisjon som ho ikkje vil ha utan filmen ho presenterer for elevane. Då kan ho leggje inn eit verdihierarki (du skal ikkje stele) utan å bli affirmativt forkynnande. Den påståelege filmen inkluderer ein påstand om at nokre verdiar er viktigare enn andre (hierarkisk), men eigentleg utan å absoluttere dette eller «forkynne» det, heilt i tråd med Benners løysing på det pedagogiske danningsparadokset. Som innleiingar til undersøkjande eller filosofiske samtalar vil det eigentleg vere stor toleranse for ulike påstandar og konklusjonar. Den pedagogiske meirverdien i høve til andre kreative former utan digitale medium (rollespel, teikningar) er kanskje ikkje stor. I ei kategorial utforsking av døme som desse ser vi at mediet neppe er avgjerande for danningsprosessen, men det kan ha noko å seie for motivasjonen, og mogleg motivasjonen er jo sentral i ei danningsdidaktisk grunngjeving.

Det er berre vedtekne etiske sanningar som blir presenterte i dei filmane studentane våre laga. Desse blir ikkje berre formidla direkte, men dei skapar føresetnaden for å skjøne løysinga på sjølve problemet så å seie nedanfrå. Ut over denne analysen av kreative verktøy, i spørsmålet om dei er affirmative eller ikkje, 
og om korleis dei peikar, er det såleis eit poeng som veks fram av denne studien som lyt avklarast teoretisk: skilnaden mellom undervisning i emne med løysingar der det er allmenn semje og emne med allmenn usemje. Dette kjem godt fram når vi ser på heile materialet i prosjektet, ikkje berre på filmane, dei som skal spore til etisk refleksjon til dømes i undersøkjande eller filosofiske samtalar. Avklarte verdispørsmål er på ein måte annleis enn uavklarte i undervisning.

For å sjå potensialet i kreative verktøy som teknologien i og med mobile einingar, er det altså mogleg å observere og studere læringsprosessen kategorialt, kva for kategoriar læraren peikar (prøver å peike) på og kva som vert oppfatta og forstått av eleven eller studenten. I det materialet vi samla inn frå studentane, er det ein klar skilnad mellom dei filmane eller presentasjonane som tek opp forteljingar med relativt klare utgangar og svar på den eine sida, og dei som ikkje har slike svar på den andre. Å undervise i etiske eller religiøse emne der det ikkje er heilt opplagt kva ein skal tru og gjere, er på ein måte lettare enn undervisninga av dei emna som er aksepterte allment i samfunnet og meir eller mindre internaliserte. Likeverdsideala og konsekvensane av dei er på ein måte så sjølvsagte at det er vanskeleg å undervise om dei på ein måte som sjølv tuftar prinsippa.

Det er ein skilnad mellom undervisninga av vedtekne sanningar og dei enno diskutable spørsmåla, mellom etiske / politiske problem versus etiske / politiske utfordringar, dvs. mellom etisk drøfting og moralisering. I døme med etiske problem utan vedtekne sanningar lyt ein skape på nytt problemet på eitt vis, der ein spelar seg inn i drøftinga på eit stadium der det framleis var opne horisontar $\mathrm{i}$ samfunnsdebatten eller for kvar enkelt, då ingen visste heilt korleis det ville ende eller kva som var heilt rett og gale.

Det som skjer i denne undervisninga, er det eg vil kalle responsiv tilbakepeiking. Å bruke digitale verktøy kreativt i undervisning på denne måten gjer at læraren kan peike på ein måte som er opnande, non-affirmativ og med eit verdihierarki. Ein har i dagens mobile einingar fleire sjangermodular tilgjengeleg til fri disposisjon i malane som programvaren etablerer. t.d. krimsjangeren der programvaren legg inn standard Hollywood-liknande malar med skummel musikk og regi. Det ein då gjer med denne teknologien, er ikkje noko prinsipielt nytt, slike malar finst jo og vart til før digitaliseringa. Men likevel kan ein gjere noko ein før ikkje gjorde i undervisning av di utstyret då ikkje var tilgjengeleg tidlegare. Læraren utfordrar eleven i denne bruken på det konkrete (enkelttilfellet) og det generelle eller kategorien, det vil eg kalle dobbelpeiking. Elevane svarer (responsiv) ved sjølv å peike dobbelt tilbake. Elevane kan då vise si djupe læring («dybdelæring») ved å peike på kva dei oppfattar når læraren har peika på noko for dei.

Lærarstudenten som arbeider på denne måten, vil kunne lære av prosessen og tankegangen kring dette. Ved å tenkje «responsiv tilbakepeiking» vil læraren berre passivt støtte prosessen mot personleg avklaring og identitet, noko som er ein 
føresetnad i alle organiserte danningsprosessar om vi følgjer Benner. Det er ein fordel med peike-teorien som didaktisk teori at han ikkje vert stadfestande. Dette er passiv støtte til prosessen mot personleg avklaring (identitet) av di læraren ikkje peikar for eller på eleven, men på saka - for eleven. Kva elevane oppfattar, er den andre delen av den kategoriale didaktikktenkinga som er så vanskeleg å lokalisere $i$ korte augneblink eller til eksamen. I svaret frå eleven i filmen eller diskusjonen om han, vil vi likevel kunne skimte han.

\section{Ei NY OG POSITIV SIDE VED DEN Digitale KOMPETANSEN}

Utdanningsdirektoratet har fastsett fire område for digital kompetanse: «[t] ilegne og behandle; produsere og bearbeide; kommunisere; digital dømmekraft» (Utdanningsdirektoratet 2012, s. 6). Men med berre fire område kan vi lett misse vesentlege delar av det den digitale teknologien kan hjelpe oss med i religionsundervisning av ulike typar og deira danningspotensiale. Grunnen til at eg har arbeidd med og ønskte å sjå nærare på dei meir kreative sidene ved digital teknologi, er at dei i pedagogisk bruk legg opp til meir aktiv bruk, noko vi kan kalle aktiv peiking, noko som igjen er viktig for den sjølvstendige forminga eller danninga. I studiar av denne typen har eg argumentert for at vi må trekkje inn analysen av sambandet mellom form og stoff (læringsmiddel og innhald, frå Klafki), samanhengen mellom eksempel og kategori som kjem med undervisninga (Klafki), og at læraren eigentleg berre kan peike (Prange). Det eg har ønskt å peike på gjennom den teoretiske presentasjonen og i forskingsmaterialet, er ein type prosess vi kan kalle responsiv tilbakepeiking, med ein effekt som svar på noko som dukkar opp innanfor ikkje-stadfestande (non-affirmativ) undervisning, det som peikar på kategoriar. Dette gjer eg i tråd med Benners non-affirmative danningsteori.

Prosjektet starta med ei litt skeptisk haldning til kva den digitale teknologien eigentleg kan gjere for undervisning i religions- og livssynfag. Men vi enda opp i meir positiv haldning til $\mathrm{m}$-teknologien i dette prosjektet, meir nysgjerrig enn skeptisk. Undervisning og læring med mobile einingar (m-læring og m-undervisning) er ein ressurs som byd på mange bruksmåtar, men som i undervisning av religion, livssyn, filosofi og etikk er til hjelp som kreative og sjølvstendiggjerande verktøy. For å forstå korleis teknologien kan hjelpe oss, lyt vi gå innom både teknologiske og pedagogiske analysar. Sjølv om mobile einingar og digitalteknologien tilsynelatande både kan spørje og utfordre, er det å vise (representativ) han er best på, altså den representative bruken slik teorien frå Prange seier det. I bruk og i dialog med ein lærar kan det likevel brukast til å spørje og utfordre. Her er den kreative bruken av mobile einingar særleg relevant.

Med enkle midlar kan ein lage film, musikk og radioprogram/podkastar der ein presenterer ulike tema og problemstillingar. Dette er kreative og aktivi- 
serande verktøy der ein enkelt kan filme, redigere, presentere og som har stort potensiale i så måte. På denne måten kan dette føre til meir aktive elevar, med dei fordelane dette har for motivasjon, kjeldetilfang, øving og refleksjon over desse. Slike verknader engasjerer utan at ein legg for sterke føringar på retninga i ei undervisning som ønskjer å danne. Kanskje ikkje noko heilt nytt, men det gjer ein optimistisk med omsyn til bruken av teknologien.

\section{LitTERATUR}

Castells, M. 1996. The information age. Economy, society and culture. Oxford: Blackwell.

Castells, M. 2001. The internet galaxy. Reflections on the internet, business and society. Oxford: Oxford University Press.

Beck, E., T. Solbrekke, M. Sutphen og E. Fremstad. 2015. «When mere knowledge is not enough. The potential of bildung as self-determination, co-determination and solidarity.» Higher Education Research and Development 34(3): 445-457.

Beck, E. og L. Øgrim. 2009. «Bruke, forstå, forandre. Hva trenger elevene å lære om IKT?». I Enter. Veien mot en IKT-didaktikk. S. Østerud (red.). Oslo: Gyldendal akademisk.

Beck, E. 2011. «Computers in education.» Nordic Journal of Digital Literacy .Special issue: $283-293$.

Benner, D. 2015. Allgemeine Pädagogik. Eine systematisch-problemgeschichtliche Einführung in die Grundstruktur pädagogischen Denkens und Handelns. Weinheim: Juventa.

Buck, F. (2017). «Gamification of Learning and Teaching in Schools. A Critical Stance.» Seminar.net: Media, technology and lifelong learning 3(1): 35-54.

Fossland, T. M. 2015. Digitale læringsformer $i$ høyere utdanning. Oslo: Universitetsforlaget.

Fuglseth, K. 2007. «E-prat (chat) som pedagogisk verktøy. Eit døme frå KRL-faget.» I T. E. Hauge, A. Lund, \& J. M. Vestøl (red.), Undervisning $i$ endring. IKT, aktivitet og design (s. 126-141). Oslo: Abstrakt.

Fuglseth, K. 2010. «A phenomenological basis for Vygotsky? A combined theory of the zone of proximal development and the theory of relevance with an example from religious education.» I M. Brinkmann (red.) Erziehung. Phänomenologische Perspektiven (s. 55-71) Würzburg, Könighausen og Neumann.

Fuglseth, K. 2013. «Kategorial konsekvens i religionsundervisninga. Innsikter frå ei refleksiv tilnærming til læraryrket.» Kunnskap til hva? Om religion $i$ skolen, (s. 239). Oslo: Akademika forlag. 
Fuglseth, K. (red.) 2018. Kategorial danning og bruk av IKT i undervisning. Oslo: Universitetsforlaget. Open tilgang. https://www.universitetsforlaget.no/ kategorial-danning-og-bruk-av-ikt-i-undervisning

Fuglseth, K. 2018a. «M-læring i etikkundervisning.» I K. Fuglseth (red). Kategorial danning og bruk av IKT i undervisning. Oslo: Universitetsforlaget: 115-130.

Gibson, J. 1977. «The theory of affordances.» I R. Shaw \& J. D. Bransford (red.), Perceiving, acting, and knowing. Toward an ecological psychology (s. 127-143). Hillsdale: Lawrence Erlbaum.

Grunnskulelova 2016. Lov om grunnskolen og den vidaregåande opplæringa (opplæringslova). LOV-1998-07-17-61 Kunnskapsdepartementet. LOV-2016-06-17-65 fra 01.08.2016.

Hansen, T. og K. Skovmand. 2011. Falles mål og midler. Århus: Klim.

Haugsbakk, G. 2010. Digital skole på sviktende grunn. Om nye muligheter og dilemmaer. Oslo: Gyldendal Akademisk.

Jank, W. \& H. Meyer. 2011. Didaktische Modelle. Berlin: Cornelsen Scriptor.

Klafki, W. (1963/1975). Studien zur Bildungstheorie und Didaktik. Weinheim: Beltz.

Klafki, W. (1964). Das pädagogische Problem des Elementaren und die Theorie der kategorialen Bildung. Weinheim: Beltz.

Klafki, W. (2002). Schultehorie, Schulforschung und Schulentwicklung im politischgesellschaftlichen Kontext. Ausgewählte Studien. Weinheim: Beltz.

Krumsvik, R. J. (red.) 2016. Digital læring $i$ skole og lærerutdanning. Oslo: Universitetsforlaget.

Lund, A. 2003. The teacher as interface. Teachers of EFL in ICT-rich environments. Beliefs, practices, appropriation. $\mathrm{PhD}$-avhandling. Oslo: Universitetet i Oslo.

Lund, A., J. Bakken og K. Engelien. 2013. «Lærerutdanning som design. Teknologirike læringsforløp og omgivelser.» Ulike forståelser av kvalitet $i$ norsk, fleksibel hoyere utdanning. Teknologi og laring på og utenfor campus. T. M. Fossland, K. R. Ramberg og E. Gjerdrum. Tromsø, Norgesuniversitetet. nr. 1/2013: 157-164.

Lund, A. og T. Hauge. 2011. «Designs for reaching and learning in technology-rich learning environments.» Nordic Journal of Digital Literacy 6(4): 258-271.

Nordkvelle, Y. 2007. «Om økseskaft, virtuelle klasserom og taktile studier på nettet. Studier i re-mediering av undervisning.» I G. Myklebost og O. Skare (red.) Om re-mediering av undervisning - og loering gjennom samarbeid. Refleksjoner over prosjekterfaringer 2006, 2/2007 (s. 209-226). Tromsø: Norgesuniversitetet.

Prange, K. 2005. Die Zeigestruktur der Erziehung. Grundriss der Operativen Pädagogik. Paderborn: Ferdinand Schöningh. 
Prange, K. og Strobel-Eisele, G. 2015. Die Formen des pädagogischen Handelns. Stuttgart: Kohlhammer.

Puentedura, R. 2009. SAMR, Learning, and Assessment. Lasta ned 10.10.17 frå http://www.hippasus.com/rrpweblog/archives/000139.html.

Utdanningsdirektoratet 2012. Rammeverk for grunnleggende ferdigheter. Oslo: Utdanningsdirektoratet. https://www.udir.no/laring-og-trivsel/ lareplanverket/grunnleggende-ferdigheter/rammeverk-for-grunnleggende-ferdigheter/ Lasta ned 9.9.19 